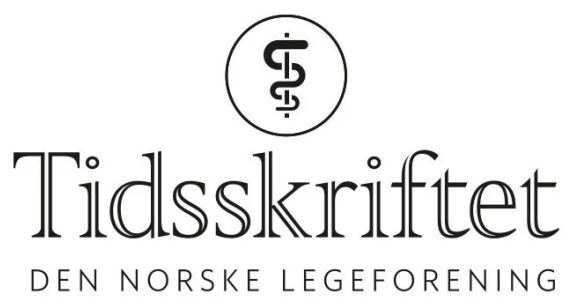

\title{
Cytokinstormer ved covid-19?
}

REDAKSJONELL KOMMENTAR

\section{KARI TVEITO}

kari.tveito@tidsskriftet.no

Kari Tveito er lege, ph.d. og medisinsk redaktør i Tidsskriftet.

Forfatteren har fylt ut ICMJE-skjemaet og oppgir ingen interessekonflikter.

\section{Alvorlig koronavirussykdom er assosiert med} hyperinflammasjon.

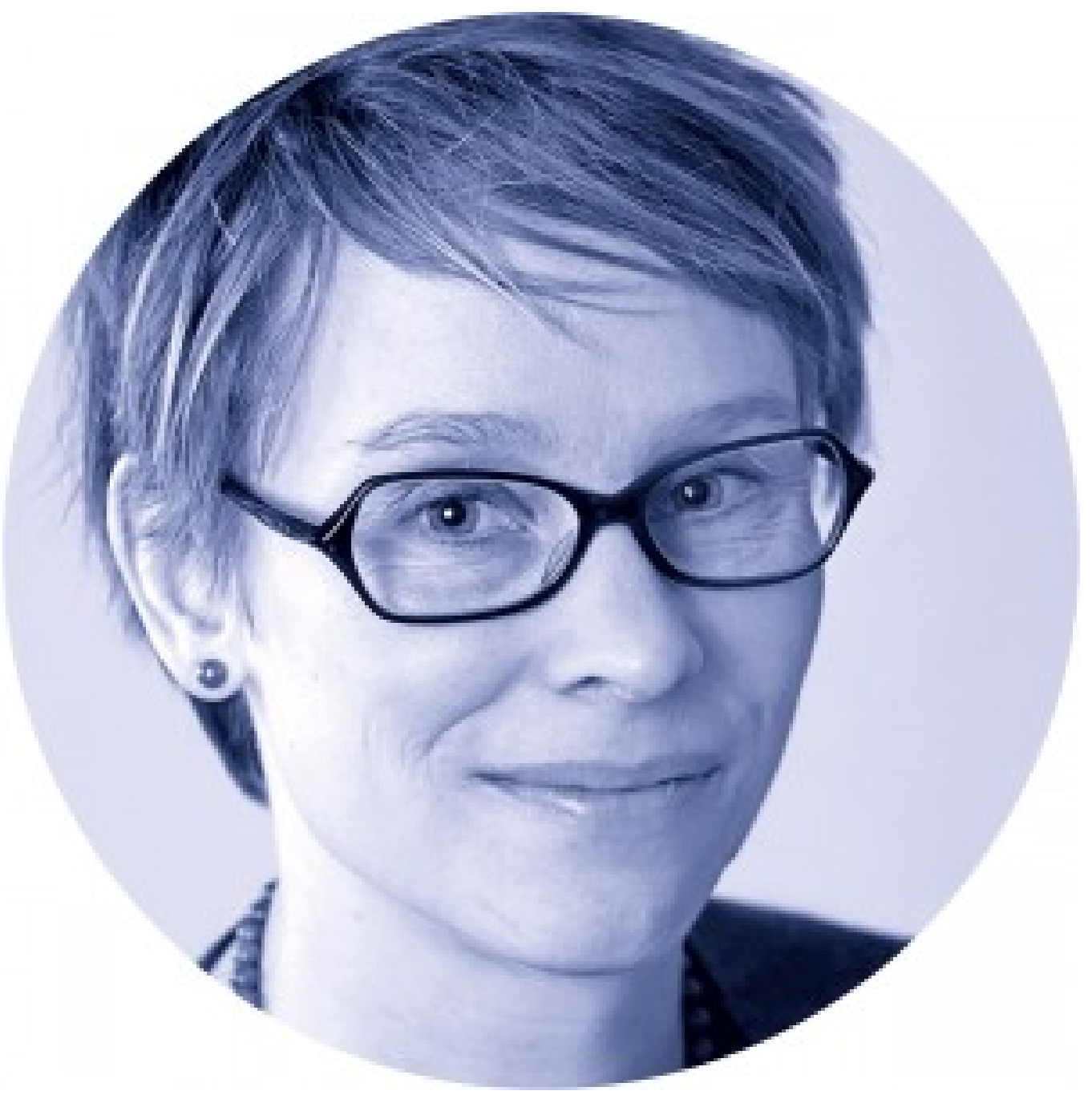


Nylig publiserte The Lancet en artikkel av Puja Mehta og medarbeidere hvor det diskuteres om sekundær hemofagocytisk lymfohistiocytose (HLH) kan være assosiert med alvorlig koronavirussykdom (covid-19) (1).

Hemofagocytisk lymfohistiocytose, som ofte omtales som en "cytokinstorm», kjennetegnes ved fulminant og fatal hypercytokinemi med multiorgansvikt (모). Hos voksne kan dette kliniske bildet utløses av virusinfeksjoner (3). Tilstanden kan også forekomme ved sepsis (4).

Puja Mehta og medarbeidere påpeker at en cytokinprofil som ligner den ved hemofagocytisk lymfohistiocytose kan sees hos de mest kritisk syke covid-19-pasientene (1, 5).

Tidsskriftet publiserer nå en kasuistikk om dette i utgangspunktet sjeldne cytokinstormsyndromet hos en pasient uten covid-19 (므). Artikkelens førsteforfatter, overlege Hallgeir Tveiten ved Lungemedisinsk avdeling ved Oslo universitetssykehus, sier følgende:

- Man har tidligere sett at det kan være viktig å behandle hemofagocytisk lymfohistiocytose med immunmodulerende medikamenter. I en studie av pasienter med tilstanden, der utløsende årsak var Epstein-Barr-virusinfeksjon, fant man at mortaliteten var 14 ganger høyere i gruppen som ikke fikk slik behandling.

Tveiten understreker at det ikke er funnet tilsvarende resultater ved andre virusinfeksjoner, og at det ikke fins randomiserte kontrollerte studier. Han mener man bør overveie spesifikk behandling dersom man mistenker hemofagocytisk lymfohistiocytose hos covid19-pasienter.

- Blokkering av interleukin-6 med tocilizumab ved akutt lungesviktsyndrom assosiert med covid-19 er i ferd med å prøves ut, og interleukin-1-blokade med anakinra diskuteres også.

Les mer i den inviterte kommentaren fra Tveiten og medarbeidere (.7.), og les også deres kasuistikk (ㅁ) .

\section{LITTERATUR}

1. Mehta P, McAuley DF, Brown M et al. COVID-19: consider cytokine storm syndromes and immunosuppression. Lancet 2020; 395: So140-6736(20)30628-o. [PubMed][CrossRef]

2. Ramos-Casals M, Brito-Zerón P, López-Guillermo A et al. Adult haemophagocytic syndrome. Lancet 2014; 383: 1503-16. [PubMed][CrossRef]

3. Rivière S, Galicier L, Coppo P et al. Reactive hemophagocytic syndrome in adults: a retrospective analysis of 162 patients. Am J Med 2014; 127: 1118-25. [PubMed][CrossRef]

4. Karakike E, Giamarellos-Bourboulis EJ. Macrophage activation-like syndrome: a distinct entity leading to early death in sepsis. Front Immunol 2019; 10: 55. [PubMed][CrossRef]

5. Huang C, Wang Y, Li X et al. Clinical features of patients infected with 2019 novel coronavirus in Wuhan, China. Lancet 2020; 395: 497-506. [PubMed][CrossRef]

6. Tveiten H, Lehne G, Aukrust P et al. En mann i 40-årene med økende pustevansker. Tidsskr Nor Legeforen 2020; 140. doi: 10.4045/tidsskr.19.0692. [CrossRef]

7. Tveiten H, Lehne G, Aukrust P et al. Hemofagocytisk lymfohistiocytose ved covid-19? Tidsskr Nor Legeforen 2020;140. doi: 10.4045/tidsskr.20.0240. [CrossRef]

Publisert: 23. mars 2020. Tidsskr Nor Legeforen. DOI: 10.4045/tidsskr.20.0239

(C) Tidsskrift for Den norske legeforening 2023. Lastet ned fra tidsskriftet.no 26. april 2023. 